\section{US universities agonize on secrecy}

Detroit

THERE are "ominous" signs that the Department of Defense (DoD) is moving towards tighter controls on sensitive scientific information, according to the universities' representative on a DoD committee on export controls. David Wilson, special assistant to the president of the University of California system and cochairman of the DoD-University Working Group on Export Controls, said at the meeting here of the American Association for the Advancement of Science that the group's efforts to strike a balance between researchers' need to publish and government's need to control sensitive though unclassified information may be undermined by the action of DoD "hard-liners" .

University researchers have accused DoD of acting capriciously in several recent clamp-downs on publication or presentation of research results. Most notable was the withdrawal of 150 papers at last year's meeting of the Society of Photo-Optical Instrumentation Engineers in San Diego after DoD officials warned that their presentation might violate export controls. DoD officials noted in particular the presence of foreign nationals at the meeting.

The DoD-University Working Group, part of a larger "forum" set up last year to discuss a wide range of issues of mutual concern, adopted a recommendation in April designed to eliminate such arbitrary actions and to make controls on unclassified results more explicit. Their chief recommendation was that academic science - unlike hardware or goods of commerce - should not be regulated by means of export controls applied after the fact, but rather by means of restrictive clauses in the initial research contracts. The universities agreed that contracts could require results to be submitted to DoD for review and comment at the same time as they are submitted for journal publication and, apparently a new concession, that restrictions could be placed on the participation of foreign nationals in sensitive research projects. In the forum's view, these restrictions would be invoked only for a small "grey area" of sensitive unclassified research and only on the recommendation of the DoD programme officer directly involved - presumably the official most knowledgeable about the science.

Wilson said that their recommendation also made clear that national security needs would have to be weighed against the wish to maintain scientific openness. The universities, many of which forbid acceptance of classified research or any research contracts that restrict freedom to publish, have been adamant on this point.

But the forum's recommendations may not carry weight. Wilson said that under a directive issued late last year (known as 2040XX), authority to regulate technology transfer - including publication or dissemination of scientific results - was given to DoD's Undersecretary for Policy (seen as a hard-liner) rather than to the Undersecretary for Research and Engineering, who is responsible for basic research contracts. Wilson says the participation of policy officials on the forum has been reluctant at best.

Complicating the picture within DoD is the work of a senior interagency group on technology transfer, chaired by an official

\section{Detroit}

THE co-author of a controversial new book ciaiming that fraud and cheating are widespread characteristics of academic science was given a predictably hostile reception over the weekend when he carried his message to the annual meeting of the American Association for the Advancement of Science (AAAS) here.

$\mathrm{Mr}$ Nicholas Wade, editorial writer for the New York Times and a former deputy editor of Nature, told a special session of the meeting that the spate of recent episodes in which respectable scientists had been discovered doctoring their research or plagiarizing that of others could not be explained by individual pathology alone. "It is not just a matter of rotten apples in the barrel", he said, "but something to do with the barrel itself."

Pointing out that new cases of fraud were now coming to light at the rate of about one a month, Wade said the discovered cases could represent only the tip of a very large iceberg. And he noted that in none of the cases had the fraud been uncovered by the traditional checking mechanisms of science - peer review, the refereeing of papers before publication and the replication of experiments.

Yet precisely these mechanisms, he argued, are used by scientists and philosophers of science to argue that research fraud is rare and, once committed, certain to be discovered. In practice, however, cheating is virtually never detected by peer reviewers or referees, and few scientists bother to replicate experiments from the published literature. The opportunities to cheat, Wade added, are becoming more frequent because of the readiness of laboratory chiefs to put their names to papers prepared by junior colleagues with little or no supervision.

Wade's argument was angrily challenged by Norton Zinder, professor of microbial genetics at Rockefeller University, New of the National Security Council. This group is attempting to overhaul the fragmented and not infrequently contradictory government-wide policy on export controls, currently spread across 14 cabinetlevel agencies in 44 offices. This group is expected to report early next year, and its policy recommendation would supersede any internal DoD policy. But Wilson and others say their chances of coming up with a coherent policy are not great.

Meanwhile, no action has yet been taken by DoD on the forum's recommendation. Yet another DoD committee, under the chairmanship of Edith Martin of the Research and Engineering Office, is now attempting to formulate an official DoD policy on the issue.

Stephen Budiansky

\title{
The system defends itself
}

York, who said science would not have survived or prospered if cheating were as prevalent as Wade's book, Betrayers of the Truth, alleged.

Zinder went on to accuse journalism of being the only profession in which fraud was prevalent, and quoted a succession of sensational medical headlines from the National Enquirer and companion publications to prove his point.

Zinder claimed that the attempt in Betrayers of the Truth to argue that science could be studied by studying its pathology was "a pretentious fallacy". Fraud was common in all walks of life and the fact that some scientists were fraudulent explained nothing about the structure of science itself. At least six of the recent cases of fraud were committed by individuals who turned out to be psychopaths who could have cheated in whatever profession they had entered.

Zinder also rejected Wade's criticisms of the traditional checking mechanisms in science. These were never intended to detect fraud but they were inexorable, he said. The fraudulent scientist had to live with the perpetual fear that he would eventually be discovered. To devise an efficient checking mechanism would, in any case, destroy everything that was good about science because it would destroy trust between colleagues.

Betrayers of the Truth received only slightly gentler treatment from other panellists. Daryl Chubin, a sociologist from the Georgia Institute of Technology, said the "cocksuredness and selfrighteousness' of the book rankled, although it was an effective assault on the conventional ideology of science. Professor Richard Westfall $\mathrm{Jr}$, a historian of science from the University of Indiana, said the book attacked a straw man nobody still believed science to be a completely objective procedure in which the checking mechanisms worked perfectly.

Peter David 